TABLE $\mathrm{v}-$ Adverse effects reported by patients

\begin{tabular}{|c|c|c|c|c|c|}
\hline & & & Indoprofen & Naproxen & Placebo \\
\hline \multicolumn{3}{|c|}{ Alimentary system: } & & & \\
\hline Indigestion & . & . & 7 & 3 & 2 \\
\hline Nausea & .. & . & 3 & 3 & 3 \\
\hline Constipation & ... & .. & 2 & 2 & 1 \\
\hline Diarrhoea & . & . & 1 & 1 & 2 \\
\hline Dry mouth & . & . & 0 & 1 & $\overline{1}$ \\
\hline \multirow{2}{*}{\multicolumn{3}{|c|}{ Central nervous system: }} & 1 & 0 & 0 \\
\hline & & & & & \\
\hline Faintness & $\ldots \quad \ldots$ & . & 0 & 1 & 0 \\
\hline Headache & . & . & 3 & 0 & 2 \\
\hline Dizziness & . & .. & 0 & 0 & 1 \\
\hline Fatigue & .. & . & 0 & 0 & 1 \\
\hline Sleeplessness. & s.. & .. & 0 & 1 & 0 \\
\hline \multirow{2}{*}{\multicolumn{3}{|c|}{ Skin: }} & 1 & 0 & 2 \\
\hline & & & & & \\
\hline $\begin{array}{l}\text { Itching } \\
\text { Rash }\end{array}$ & . & . & 0 & 0 & 1 \\
\hline \multirow{4}{*}{\multicolumn{3}{|c|}{$\begin{array}{l}\text { Other: } \\
\text { Difficulty in micturition } \\
\text { Frequency of micturition } \\
\text { Arthritis worse }\end{array}$}} & 0 & 0 & 0 \\
\hline & & & 1 & 0 & 0 \\
\hline & & & 1 & 0 & 0 \\
\hline & & & 0 & 0 & 4 \\
\hline \multicolumn{3}{|c|}{ Total } & 20 & 12 & 20 \\
\hline
\end{tabular}

over the others. Huskisson $e^{2} \mathrm{al}^{2}$ has suggested that any one nonsteroidal drug is effective in some of the population treated, so the existing "best" drug will by no means be suitable for all patients. Conversely, the "worst" drug in this group will be effective in some patients. There is no way of predicting which patients will respond best to which treatment. This suggests that there is still room for a new effective anti-inflammatory analgesic of low toxicity and high acceptability.

Animal experiments have shown that indoprofen appears to have anti-inflammatory effects at least equivalent to those of phenylbutazone and indomethacin. ${ }^{3}$ In man the analgesic properties have been well demonstrated in comparison with ibuprofen in the treatment of osteoarthritis ${ }^{13}$ and in comparison with indomethacin and placebo. ${ }^{6}$ The combination of this analgesic effect in man and the finding of anti-inflammatory effects in the animal experiments led us to conclude that the drug should be studied in rheumatoid arthritis.

Patient preference is considered to be an important test of a new anti-inflammatory analgesic agent. Previous studies have shown that naproxen $(500 \mathrm{mg} /$ day $)$ is the most preferred antiinflammatory analgesic agent, ${ }^{2}$ but our patients found indoprofen $800 \mathrm{mg} /$ day significantly better than naproxen $500 \mathrm{mg} /$ day. Indoprofen also relieved pain and improved grip strength better than naproxen.

In all the other values studied, although both naproxen and $\frac{3}{\Phi}$ indoprofen were effective and better than placebo, the trend was in favour of indoprofen. Both indoprofen and naproxen $\div$ treatments were associated with a slight but insignificant fall in $\overrightarrow{\vec{F}}$ haemoglobin, but the ESR fell on neither. In terms of toxicityo there were a few more cases of indigestion with indoprofen than $\overline{0}$ with naproxen, but these were mild and did not cause any patient $\frac{\bar{\sigma}}{}$ to stop treatment.

Our results therefore suggest that indoprofen is at least as effective as existing anti-inflammatory analgesic treatment in ${ }^{\infty}$ rheumatoid arthritis and that it might be better tolerated.

We thank Dr W Groppi of Messrs Carlo Erba, Milan, for supplies $\vec{\omega}$ of indoprofen; and $\operatorname{Dr} R$ Kohn and $\operatorname{Dr} J$ F Harper of Advisory Services (Clinical and General) Ltd, London, for their help throughout 3 the course of this study.

\section{References}

${ }^{1}$ Huskisson, E C, et al, British Medical fournal, 1974, 1, 176.

2 Huskisson, E C, et al, British Medical fournal, 1976, 1, 1048.

${ }^{3}$ Buttinoni, A, et al, Arzneimittel-Forschung, 1973, 23, 1100.

${ }^{4}$ Fuccella, L M, et al, European Fournal of Clinical Pharmacology, 1973,6 256.

5 Tammassia, V, et al, paper presented at VII International Symposium on Clinical Pharmacology, Pavia, 1976

6 Tammassia, V, et al, European fournal of Clinical Pharmacology, 1976, 19, 257.

${ }^{7}$ Marcolongo, R, et al, fournal of Clinical Pharmacology, 1977, 17, 48.

8 Ventafridda, et al, Clinical Pharmacology and Therapeutics, 1974, 17, 284.

9 Porro, G, et al, Journal of International Medical Research, 1977, 5, 155.

10 Ropes, M, et al, Annals of Rheumatic Diseases, 1959, 18, 49.

11 Berry, H, and Huskisson, E C, Fournal of Clinical Trials, 1971, 13, 1100.

12 Ritchie, D M, et al, Quarterly fournal of Medicine, 1968, 37, 393.

13 Peruzza, M, et al, International fournal of Clinical Pharmacology, 1976, ֻू 14, 81 .

\title{
Bronchopulmonary infection due to Branhamella catarrhalis: 11 cases assessed by transtracheal puncture
}

\author{
G NINANE, J JOLY, M KRAYTMAN
}

British Medical fournal, 1978, 1, 276-278

\section{Summary and conclusions}

Transtracheal punctures were performed in 193 miners of anthracosilicotic coal who presented with an acute exacerbation of chronic bronchitis. The transtracheal aspirates were bacteriologically positive in 104 patients. Branhamella catarrhalis was isolated in 15 patients; 10 of these responded to chemotherapy, as shown by the

\footnotetext{
Centre Médico-technique, Fonds des Maladies Professionnelles, Morlanwelz, Belgium

G NINANE, MD J JOLY, MD

Hôpital Universitaire Brugmann, Université Libre de Bruxelles M KRAYTMAN, MD
}

resolution of all symptoms and the disappearance of the $\frac{7}{0}$ organism on a repeat transtracheal puncture performed 48 hours after the end of treatment. One ampicillin- $\tilde{N}$ treated patient, whose bronchial secretions yielded a $\omega$ beta-lactamase-producing $B$ catarrhalis, showed no improvement. But subsequent treatment with cefuroxime was followed by clinical and bacteriological recovery.

B catarrhalis probably acted as an opportunistic $\stackrel{\infty}{+}$ respiratory pathogen in these patients, who were probably compromised hosts in view of their clinical history. $\frac{O}{\mathbb{D}}$ B catarrhalis normally responds to the penicillins $\stackrel{?}{\rightarrow}$

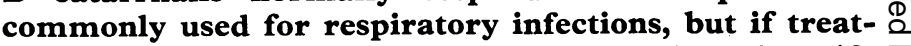
ment fails a transtracheal puncture is essential to identify the strain and determine an appropriate antibiotic.

\section{Introduction}

Branhamella catarrhalis is classically considered to be nonpathogenic for the respiratory tract. Nevertheless, a case of 
fatal $B$ catarrhalis pneumonia in a patient with multiple myeloma has recently been described. ${ }^{1}$ The diagnosis in that case was based on the bacteriological results of a transtracheal aspirate. We used the same diagnostic procedure to examine 193 miners of anthracosilicotic coal who presented with acute bronchopulmonary infection.

\section{Patients and methods}

All patients admitted to our hospital are retired coalminers with anthracosilicosis. These patients have suffered from emphysema or chronic bronchitis, or both, for many years, and have frequent episodes of acute bronchopulmonary infection, which are treated with various antibiotics. Furthermore, they are either chronically or intermittently on corticosteroid and bronchodilator treatment for chronic bronchitic asthma. Lung function tests (vital capacity, forced expiratory volume in one second, residual volume, airway resistance, and alveolarcapillary diffusion) invariably show abnormal values compatible with obstructive or restrictive lung disease, or both.

Patients who presented with acute bronchopulmonary infection, as shown by recent exacerbation of dyspnoea, fever, purulent sputum, and corresponding clinical signs, were submitted to a transtracheal puncture. ${ }^{2}$ In each case a chest $x$-ray picture was taken and blood samples were taken for the usual laboratory tests, including erythrocyte sedimentation rate (ESR) and differential leucocyte counts. In patients who had received antibiotics before their admission treatment was stopped and the transtracheal puncture was performed 48 hours later. The procedure was explained to each patient, and all gave their informed consent.

Transtracheal aspirates that were shown on microscopy to contain epidermoid cells were considered to be contaminated by oropharyngeal secretions and discarded as being unrepresentative of the microbial flora responsible for the respiratory infection. The remaining aspirates were examined by direct Gram stain and cultured on blood agar chocolate agar, and MacConkey agar. Micro-organisms were identified according to standard procedures. ${ }^{3}$ Branhamella catarrhalis was identified by the following morphological, physiological, and biochemical characteristics: Gram-negative, oxidase-positive diplococci; catalasepositive; negative for pigment, haemolysis, and acid from glucose, lactose, maltose, and sucrose; nitrate reduced; DNase-positive. The minimum inhibitory concentration (MIC) of the antibacterial agents used was determined in brain-heart infusion broth eventually supplemented with Isovitalex or $\mathrm{X}$ and $\mathrm{V}$ factors for fastidious organisms, ${ }^{4}$ or both. $\beta$-Lactamase was assayed according to the technique of $\mathrm{O}^{\prime}$ Callaghan et al. ${ }^{5}$ Patients in whom the transtracheal aspirates yielded pus cells and micro-organisms on the Gram stain and a positive culture received antibiotic treatment for seven to 10 days.

The drugs used were ampicillin and co-trimoxazole, two commonly used antibacterial agents for respiratory infections, and cefuroxime, a new cephalosporin claimed to be active against $\beta$-lactamaseproducing bacteria. ${ }^{6}{ }^{7}$ Ampicillin was given either orally, $4 \mathrm{~g} /$ day for 10 days, or intramuscularly, $3 \mathrm{~g} /$ day for seven days; co-trimoxazole was given at a dosage of $320 \mathrm{mg}$ trimethoprim and $1600 \mathrm{mg}$ sulphamethoxazole per day for 10 days, and cefuroxime was given intramuscularly, $3 \mathrm{~g} /$ day for seven days.

Forty-eight hours after the end of treatment the patients underwent a repeat transtracheal puncture. The effect of treatment was assessed by the resolution of the clinical features and by the bacteriological results of the repeat transtracheal puncture. The respiratory infection was considered to be cured only when the transtracheal aspirate was sterile.

\section{Results}

One hundred and ninety-three patients underwent an initial transtracheal puncture. Three aspirates were considered to be contaminated by oropharyngeal secretions and discarded. Of the 190 acceptable samples, 104 yielded a positive culture. The micro-organisms isolated were: Haemophilus influenzae (44), Streptococcus pneumoniae (22), Branhamella catarrhalis (14), Pseudomonas aeruginosa (8), Corynebacterium pseudodiphtheriticum (1), Salmonella typhimurium (1), Escherichia coli (1), Neisseria meningitidis (1), $H$ influenzae and Str pneumoniae (10), H influenzae and "viridans" streptococci (1), and $B$ catarrhalis and $H$ influenzae (1).

$B$ catarrhalis was therefore present in 15 patients, 14 times as a pure culture, and once in association with $H$ influenzae. Four of these patients could not be submitted to a repeat transtracheal puncture, and were therefore excluded. The bacteriological findings and the antibiotics administered to the remaining 11 patients are shown in the table. In 10 patients clinical improvement was rapid: they became afebrile after 48 hours of treatment, and by the end of treatment their coughs had disappeared, their sputum was mucoid, and the initially raised ESR and white cell counts had returned to normal. Repeat transtracheal puncture, performed 48 hours after the end of treatment was sterile.

The remaining patient (case 9) showed a very different clinical picture. His initial transtracheal puncture yielded $B$ catarrhalis, and he was treated with intramuscular ampicillin $3 \mathrm{~g} /$ day for seven days. Meanwhile, the bacteriological laboratory reported that the isolated strain was $\beta$-lactamase-positive and that its MIC was $16 \mathrm{mg} / \mathrm{l} \mathrm{ampi-}$ cillin-a considerably higher value than the mean MIC for ampicillin of the other $B$ catarrhalis strains. At the end of treatment he showed no clinical improvement, his fever had not abated, and his sputum was still purulent. The repeat transtracheal puncture again yielded a pure culture of $\beta$-lactamase-producing $B$ catarrhalis, with the same MIC for ampicillin. As the MIC for cefuroxime, determined on the first isolate, was $2 \mathrm{mg} / \mathrm{l}$ this antibiotic was given intramuscularly $3 \mathrm{~g} /$ day for seven days. This time the patient improved rapidly and his sputum was mucoid when the treatment was stopped. A third transtracheal puncture, performed 48 hours later, was sterile. ${ }^{8}$

\section{Discussion}

$B$ catarrhalis, formerly classified as Neisseria catarrhalis, ${ }^{9}$ is a normal inhabitant of the nasopharynx and is classically considered to be non-pathogenic. Nevertheless, this apparently innocuous organism has occasionally caused subacute endocarditis ${ }^{10}$ and meningitis. ${ }^{11}$ Even more often it has caused acute otitis media in children, ${ }^{12-15}$ being recovered in pure culture in the ear exudate in $1.3-5 \%$ of cases. Hitherto it has not been recognised as a respiratory pathogen. Nevertheless, a fatal $B$ catarrhalis pneumonia in a patient with multiple myeloma has recently been described. ${ }^{1}$ Our results provide further evidence of the pathogenic potential of this organism in the respiratory tract.

In our series of 104 bacteriologically positive transtracheal

Clinical and bacteriological data in 11 patients with respiratory infection caused by $B$ catarrhalis

\begin{tabular}{|c|c|c|c|c|c|}
\hline Case No & $\begin{array}{l}\text { Initial } \\
\text { transtracheal aspirate }\end{array}$ & $\begin{array}{l}\text { Antibacterial treatment } \\
\text { Drug }\end{array}$ & $\underset{(\mathrm{mg} / \mathrm{l})}{\mathrm{MIC}}$ & $\begin{array}{l}\text { Clinical status } \\
\text { at end of treatment }\end{array}$ & $\begin{array}{l}\text { Control } \\
\text { transtracheal aspirate }\end{array}$ \\
\hline $\begin{array}{r}1 \\
2 \\
3 \\
4 \\
5 \\
6 \\
7 \\
8 \\
9 \\
10 \\
11\end{array}$ & $\begin{array}{c}\text { B catarrhalis } \\
\text { ” } \\
\# \\
\# \\
\# \\
\# \\
\# \\
\text { B catärhalis and } \\
\text { H influenzae } \\
\text { B catarrhalis }\end{array}$ & $\begin{array}{l}\text { Ampicillin* } \\
\text { Ampicillin } \\
\text { Ampicillin* } \\
\text { Co-trimoxazole } † \\
\text { Ampicillin } \ddagger \\
\text { Ampicillin } \ddagger \\
\text { Cefuroxime } \\
\text { Ampicillin } \ddagger \\
\text { Ampicillin } \ddagger \\
\text { Cefuroxime } \ddagger \\
\text { Ampicillin } \ddagger\end{array}$ & $\begin{array}{l}\leqslant 0 \cdot 125 \\
\# " \\
\# \\
\# \\
" \# \\
16 " \\
\leqslant 0 \cdot 125 \\
"\end{array}$ & $\begin{array}{l}\text { Good } \\
\text { ”, } \\
\# \\
\# \\
\text { ”, } \\
\text { Unchanged } \\
\text { Good } \\
\text { ” }\end{array}$ & $\begin{array}{l}\text { Sterile } \\
\# \\
\# \\
\# \\
\# \\
\text { \#" catarrhalis } \\
\text { Sterile } \\
\#\end{array}$ \\
\hline
\end{tabular}

*Ampicillin $4 \mathrm{~g} /$ day orally for 10 days. $+3 \mathrm{~g} /$ day intramuscularly for seven days.

$\ddagger$ Co-trimoxazole $160 \mathrm{mg}$ trimethoprim and $800 \mathrm{mg}$ sulphamethoxazole orally twice a day for 10 days. 
aspirates, $B$ catarrhalis was recovered in 15 patients $\left(14.4{ }_{0}^{\circ}\right)$; other series have shown rates of recovery of $4 \%{ }^{16}$ and $7 \%{ }^{17}$ In our series $B$ catarrhalis was isolated from bronchial secretions obtained by transtracheal puncture, which is widely accepted as the procedure of choice to collect uncontaminated material from the lower respiratory tract. ${ }^{21718}$

As we discarded transtracheal aspirates that included epidermoid cells, the possibility of contamination of these aspirates by oropharyngeal secretions can be ruled out.

In nine of the 10 patients who were followed up bacteriologically $B$ catarrhalis was isolated as a pure culture and the organism could be observed intracellularly in the leucocytes on the Gram stain. In one case it was associated with $H$ influenzae. Two bacterial species are often found to be associated in acute bronchopulmonary infection. ${ }^{19} \mathrm{H}$ influenzae and Str pneumoniae were observed in 10 of our 104 patients and $H$ influenzae and "viridans" streptococci in another one.

We observed a positive correlation between resolution of the clinical features and the disappearance of $B$ catarrhalis from the respiratory tract. One patient (case 9) showed no clinical improvement despite ampicillin treatment, and a repeat transtracheal puncture yielded the same $\beta$-lactamase-producing, ampicillin-resistant, $B$ catarrhalis strain that had been present at the initial puncture. When cefuroxime, a cephalosporin active against this strain, was given clinical and bacteriological improvement ensued. $\beta$-Lactamase-producing strains of $B$ catarrhalis have recently been isolated from nasopharyngeal swabs obtained from children with suspected whooping cough. ${ }^{20}$

$B$ catarrhalis, a normal inhabitant of the nasopharynx, presumably becomes pathogenic by spreading downwards to the lower respiratory tract, producing pneumonia. Similarly, pathogenesis of acute otitis media in children due to $B$ catarrhalis is most probably explained by an upward spread of the organism to the middle ear. ${ }^{13}$ But additional factors present in our patients most probably predisposed them to a $B$ catarrhalis pulmonary infection. Because of their clinical characteristics, our patients could be considered to be compromised hosts. They were all miners of anthracosilicotic coal who had altered pulmonary function; they had all suffered repeated infectious episodes, which must have damaged the bronchial ciliary mechanism; and they all received frequent corticosteroid treatment, which has been shown to have immunodepressant activity. ${ }^{21}$ The recently reported case of fatal $B$ catarrhalis pneumonia also occurred in an immunodeficient host. Thus, $B$ catarrhalis seems to behave as an opportunistic pulmonary invader rather than a primary pathogen.

$B$ catarrhalis is sensitive to the penicillins commonly used in respiratory infections. But these antimicrobial agents will notw be effective against $\beta$-lactamase-producing strains. Thus when 3 usual treatment fails a transtracheal puncture is essential to identify accurately the causative organism and determine itsc. in-vitro sensitivity to antibiotics.

We thank Dr S Selwyn for reviewing our manuscript and offering his advice.

\section{References}

${ }^{1}$ McNelly, D J, Kitchens, C S, and Kluge, R M, American Review of ${ }^{\circ}$ Respiratory Diseases, 1976, 114, 399.

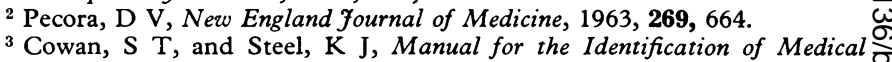
Bacteria. London, Cambridge University Press, 1974.

${ }^{4}$ Anderson, T H, in Manual of Clinical Microbiology, ed J E Blair, E H. Lenette, and J P Truant, p 299. Bethesda, American Society for Micro--

5 O'Callaghan, C H, et al, Antimicrobial Agents and Chemotherapy, 1972, 1, 283

${ }^{6}$ O'Callaghan, C H, et al, fournal of Antibiotics, 1976, 29, 29.

7 Sykes, R B, Griffiths, A, and Ryan, D M, Antimicrobial Agents and 0 के Chemotherapy, 1977, 11, 599.

${ }^{8}$ Ninane, G, Joly, J, and Kraytman, M, Lancet, 1977, 2, 149.

${ }^{9}$ Catlin, B W, International fournal of Systemic Bacteriology, 1970, 20, 155 . T

${ }^{10}$ Clarke, R M, and Haining, R B, Annals of Internal Medicine, 1936, 10, 117.

${ }_{11}$ Pfister, L E, et al, Fournal of the American Medical Association, 1965, 193, 149.

12 Coffey, J D, Pediatrics, 1966, 38, 25.

${ }^{13}$ Halsted, C, et al, American fournal of Diseases of Children, 1968, 115, 542. $\overrightarrow{.}$

${ }^{14}$ Nilsson, B W, et al, Pediatrics, 1969, 43, 351.

${ }^{15}$ Kamme, C, Scandinavian fournal of Infectious Diseases, 1970, $2,117$.

${ }_{16}$ Schoutens, E, et al, Biomedicine, 1973, 19, 160.

17 Schreiner, A, Digranes, A, and Myking, O, Scandinavian fournal of Infectious Diseases, 1972, 4, 49.

${ }^{18}$ Kalinske, R W, et al, New England fournal of Medicine, 1967, 276, 604.

${ }^{19}$ May, J R, in Chemotherapy of Chronic Bronchitis, 2nd edn, p 38. London, English University Press Ltd, 1972.

${ }^{20}$ Malmvall, B E, Brorsson, J E, and Johnsson, J, fournal of Antimicrobial Chemotherapy, 1977, 3, 374 .

${ }^{21}$ Tager, I, and Speizer, F E, New England fournal of Medicine, 1975, 292, 을 563.

(Accepted 24 November 1977)

\section{SIDE EFFECTS OF DRUGS}

\section{Delayed respiratory depression after use of fentanyl during anaesthesia}

Concern about polluting operating theatres with anaesthetic gases and the wish to avoid using volatile inhalational agents have lead to the increased use of potent narcotics given intravenously during anaesthesia. Drugs such as fentanyl and phenoperidine used as supplements to controlled ventilation with nitrous oxide, oxygen, and a muscle relaxant ensure that the patient remains asleep during surgery, and their analgesic effects are useful in the immediate postoperative period.

We describe three cases in which fentanyl was used as described above but in which severe respiratory depression occurred several hours after apparent recovery from the anaesthetic.

\section{Case 1}

An 18-year-old Pakistani man weighing $64 \mathrm{~kg}$ was admitted for condylotomy under general anaesthesia because ankylosis of the left temporo- mandibular joint, caused by a typhoid infection at the age of 2 , restricted jaw opening to $7 \mathrm{~mm}$. Papaveretum $10 \mathrm{mg}$ and hyoscine $0.2 \mathrm{mg}$ were given intramuscularly one hour preoperatively with little sedative effect. Anaesthesia was induced with intravenous propanidid $450 \mathrm{mg}$, and blind nasalo intubation was performed with a $7.5 \mathrm{~mm}$ cuffed, streamlined endotracheal tube while the patient breathed halothane in oxygen. Intravenous pancuro- $\sigma$ nium (Pavulon) $7 \mathrm{mg}$ and fentanyl (Sublimaze) $0.2 \mathrm{mg}$ were given and the lungs ventilated by using an East-Radcliffe ventilator and Bain anaesthetice circuit with a fresh-gas flow of nitrous oxide and oxygen of $71 / \mathrm{min}$. During the operation more fentanyl $(0.275 \mathrm{mg})$ and pancuronium $(5 \mathrm{mg})$ were given in divided doses. At the end of surgery, which took three and three-quarter hours, atropine $1.2 \mathrm{mg}$ and neostigmine $3.75 \mathrm{mg}$ were given. The patient was extubated when spontaneous breathing resumed. He coughed imme- $\frac{\mathbb{\Phi}}{\mathbb{D}}$ diately and was talking within a few minutes.

The patient's condition remained satisfactory while he was in the recovery room, and one hour later he was returned to the ward, where he talked coherently to visitors. About four hours after the last increment of fentanyl he became increasingly drowsy with a slow, grunting respiration of three per minute. When he could not be roused laryngoscopy was performed and heO was ventilated with oxygen by means of an Ambu bag. Some pharyngeal oedema was present. An anaesthetist, noting the pinpoint pupils, gave intravenous naloxone (Narcan) $0.4 \mathrm{mg}$ with dramatic effect: the patient? awoke immediately and respiration returned to normal. He needed no further naloxone and made an uneventful recovery. No postoperative medication had been given. 